Zeszyty Naukowe Szkoły Głównej Gospodarstwa Wiejskiego w Warszawie

Problemy Rolnictwa Światowego tom 18 (XXXIII), zeszyt 1, 2018: 88-99

DOI: $10.22630 /$ PRS.2018.18.1.8

Katarzyna Klosowicz-Toborek $^{1}$

Uniwersytet Ekonomiczny w Krakowie

\title{
Istota protekcjonizmu w dziewiętnastym wieku oraz współcześnie ${ }^{2}$
}

\section{The Essence of Protectionism in the Nineteenth Century and Nowadays}

\begin{abstract}
Synopsis. Pomimo działalności WTO idea protekcjonizmu jest wciąż aktualna. Większość państw oficjalnie opowiada się za liberalizmem, a przy tym ogranicza wymianę handlową. Działalność ta ulega nasileniu w okresach stagnacji gospodarczej oraz w związku z różnicami rozwojowymi między uczestnikami rynku światowego. To właśnie zacofanie gospodarcze XIX-wiecznych Niemiec wpłynęło na stworzenie wielu oryginalnych myśli, a wśród nich tych, które odnosiły się do sposobu prowadzenia handlu zagranicznego. Warto zatem zbadać i porównać neoprotekcjonizm z protekcjonizmem prezentowanym przez XIX-wiecznych ekonomistów. Analiza współczesnego i XIX-wiecznego protekcjonizmu wskazuje, że istota tych pojęć nie różni się bowiem neoprotekcjonizm i jego XIX-wieczny odpowiednik realizują te same cele, aczkolwiek przy wykorzystaniu innych środków.
\end{abstract}

Slowa kluczowe: protekcjonizm, niemiecka szkoła historyczna, neoprotekcjonizm, polityka handlowa

\begin{abstract}
Despite the buoyant activity of the WTO, the idea of protectionism is still valid. Most countries officially support liberalism while limiting trade. This activity is intensified during periods of economic stagnation and in relation to the developmental differences among the participants in the world market. The economic backwardness of nineteenth-century Germany influenced the development of many original ideas, including those related to foreign trade. Therefore, it is worth examining and comparing neoprotectionism to the protectionism presented by nineteenth-century economists. The analysis of contemporary and nineteenth century protectionism indicates that the essence of these concepts does not differ, because neoprotectionism and its nineteenth-century equivalent fulfill the same aims, but using different measures.
\end{abstract}

Key words: protectionism, German historical school of economy, neoprotectionism, trade policy

JEL Classification: B15, B17, F13

\section{Wprowadzenie}

Wydawać by się mogło, że współcześnie, w świecie, w którym aktywnie działa Światowa Organizacja Handlu (ang. World Trade Organization, WTO) idea protekcjonizmu jest już nieaktualna. Działania podejmowane przez WTO mają na celu usuwanie wszelkich przeszkód ograniczających handel międzynarodowym, a także tworzenie równych szans

\footnotetext{
${ }^{1}$ mgr, Katedra Historii Myśli Ekonomicznej, Wydział Ekonomii i Stosunków Międzynarodowych UE w Krakowie, ul. Rakowicka 27, 31-510 Kraków, e-mail: klosowicz.toborek@gmail.com

2 Publikacja została sfinansowana ze środków MNiSW przyznanych Wydziałowi Ekonomii i Stosunków Międzynarodowych Uniwersytetu Ekonomicznego w Krakowie na badania dla młodych naukowców oraz uczestników studiów doktoranckich.
} 
wymiany handlowej. Większość krajów oficjalnie opowiada się za liberalizmem handlu, jednak naciski wewnętrzne, skłaniają rządy do stosowania protekcjonizmu. Szczególnie uwidacznia się to $\mathrm{w}$ okresach kryzysów gospodarczych. Najlepszym tego przykładem jest kryzys, który wybuchł w $2008 \mathrm{r}$. oraz ten, który miał miejsce w latach 70 . XX w.

XIX w. to okres w dziejach ludzkości, który charakteryzował się szerokim i rozłożony $\mathrm{w}$ czasie spektrum zmian. W tym okresie w wielu krajach europejskich miała miejsce rewolucja przemysłowa. Przejawem rozwijającego się kapitalizmu było powstawanie coraz większej różnicy między biednymi a bogatymi. W okresie wielkich przemian, w pierwszej połowie XIX w., niemieccy ekonomiści generowali wiele oryginalnych idei, a wśród nich te odnoszące się do sposobu prowadzenia handlu zagranicznego.

Warto zatem zastanowić się co łączy a co różni współczesny protekcjonizm (neoprotekcjonizm) od protekcjonizmu przedstawianego przez XIX-wiecznych ekonomistów. Założony powyżej cel badawczy, a także analiza dostępnej literatury pozwoliły postawić następującą hipotezę: współczesny i XIX-wieczny protekcjonizm realizują te same cele, aczkolwiek za pomocą innych środków.

Badania były prowadzone zgodnie $\mathrm{z}$ metodologią odpowiednią dla historii myśli ekonomicznej. Problem protekcjonizmu został osadzony w XIX-wiecznych realiach społeczno-gospodarczych, co wymusiło zastosowanie metody badawczej polegającej na tworzeniu rekonstrukcji historycznych. Jednocześnie idee XIX-wiecznych ekonomistów zostały skonfrontowane ze współczesną wiedzą makroekonomiczną dotyczącą tego problemu. Ten drugi sposób prowadzenia badań opiera się na metodzie tworzenia rekonstrukcji racjonalnych. Następnie XIX-wieczny protekcjonizm został porównany $\mathrm{z}$ neoprotekcjonizmem.

\section{Polityka protekcjonizmu w dziewiętnastowiecznej myśli ekonomicznej}

W XIX w. rozgorzała dyskusja nad podstawami założeniami i metodą ekonomii klasycznej. Rozważania na ten temat podjęli między innymi niemieckojęzyczni ekonomiści, których zwykło się nazywać niemiecką szkołą historyczną. Kierunek historyczny rozwijał się $\mathrm{w}$ wielu krajach, jednak $\mathrm{z}$ największym powodzeniem w Niemczech (Stankiewicz, 2007, s. 147).

Niemiecka szkoła historyczna kwestionowała metody klasyków, którzy stosowali przede wszystkim indywidualizm metodologiczny, metody dedukcji i indukcji. Historycy podkreślali, że każdy problem/sytuacja jest wyjątkowa i należy brać pod uwagę czas oraz miejsce, a wyjaśnienie bieżących problemów i wydarzeń powinno być oparte o fakty historyczne i dane statystyczne (Szarzec, 2013, s. 40-41). Co więcej, wątpliwości wzbudzał również dominujący w ekonomii klasycznej pogląd, że rynki automatycznie dążą do równowagi, przez co laissez-faire jest najlepszą polityką rządu.

Niewątpliwie wpływ na poglądy niemieckich ekonomistów miała sytuacja społecznogospodarcza. Początek XIX w. to czas, w którym kapitalizm powoli zastępował system feudalny. Typowe dla niego rozbicie dzielnicowe, w Niemczech przybrało skrajną formę. Poszczególne jednostki administracyjne były odseparowane od siebie nie tylko granicami, ale również barierami celnymi, co negatywnie oddziaływało na stosunki społeczne i życie polityczne. Bariery handlowe, różne systemy monetarne, różne systemy miar i wag nie sprzyjały wymianie handlowej i współpracy gospodarczej. Rozbicie dzielnicowe niekorzystnie wpływało na rozwój gospodarki niemieckiej mającej charakter rolniczy 
z wieloma pozostałościami feudalnymi. Nadal dominowało poddaństwo i pańszczyzna w rolnictwie, a także rzemiosło cechowe w przemyśle. Brakowało zatem wolnej siły roboczej. Co więcej, import tańszych angielskich wyrobów doprowadzał rodzimych producentów do ruiny, bowiem rozproszony rynek nie był konkurencyjny. Utworzenie jednolitego rynku i silnej gospodarki stało się koniecznością (Staniewicz, 2007, s. 147-148).

Na gruncie filozofii niemieckiej okresu romantyzmu wyrosła szkoła historyczna, która wyszła od krytyki uniwersalności teorii klasycznej, czyli przekonania, że klasyczną teorię ekonomiczną można stosować w każdym państwie w dowolnym czasie. Przedstawiciele niemieckiej szkoły historycznej twierdzili, że poglądy Smitha, Ricarda i pozostałych klasyków są słuszne, ale dla dobrze rozwiniętych, uprzemysłowionych krajów, takich jak Anglia, nie są natomiast słuszne dla rolniczej gospodarki Niemiec. Niemiecka szkoła historyczna nie była tworem całkowicie jednorodnym, pomiędzy jej przedstawicielami zachodziły pewne różnice. Do najważniejszych autorów starszej szkoły historycznej zaliczany jest Friedrich List ${ }^{3}$ (Landreth i Colander, 2005, s. 349).

Friedrich List (1780-1846) ze względu na swoje pochodzenie nie miał możliwości kształcenia się. Dopiero przeprowadzka do Tybingi pozwoliła na podjęcie pracy w urzędzie powiatowym i uczęszczanie na wykłady. W 1817 r. został mianowany profesorem nauk administracyjnych. Był założycielem Niemieckiego Związku Handlu i Rzemiosła, który dążył do zniesienia ceł wewnętrznych. List naraził się tym rządowi, przez co zmuszony był do zrezygnowania z pracy urzędnika oraz z profesury. Publikacja ostrej petycji sprawiła, że musiał emigrować do Francji. Po powrocie do kraju, został uwięziony, a następnie wyjechał do Stanów Zjednoczonych. W 1827 r. opublikował „Grundriß der amerikanischen politischen Ökonomie" (ang. Outlines of American Political Economy), a kilkanaście lat później „Das Nationale System der Politischen Ökonomie“ (ang. The National System of Political Economy). Doświadczenia z pobytu w Stanach wykorzystał w trakcie przygotowywania książek. Jego poglądy trafiły na podatny grunt $\mathrm{w}$ Stanach Zjednoczonych, przez co często nazywany jest ojcem amerykańskiego protekcjonizmu (Encyklopedia Britannica Friedrich List).

Analizując poglądy F. Lista warto wyjść od ogólnego opisu systemu. Tytuł największego dzieła Lista, „Narodowy system ekonomii politycznej”, wskazuje, że punktem wyjścia i podstawowym przedmiotem analizy nie jest tak jak u klasyków - jednostka, lecz naród. We wstępie do swojego dzieła F. List podkreśla, że cały system opiera się na istocie narodu, jako „członie pośrednim między indywidualnościq a ludzkościq”, a przy tym naród jest głównym wyróżnikiem zbudowanego przez niego systemu (List, 1856, s. XLIII).

F. List przeprowadził dogłębną analizę dziejów gospodarczych i społecznych wybranych krajów europejskich (Anglia, Hiszpania, Portugalia, Francja, Niemcy, Rosja) oraz Stanów Zjednoczonych. Niemiec skupił się na polityce handlowej i wymianie międzynarodowej. Analiza ta przyniosła teorię stadiów rozwoju, w ramach której List wyróżnił pięć głównych stadiów: stan dzikości, stadium pasterstwa, stadium rolnictwa, stadium rolniczo-przemysłowe, stadium rolniczo-przemysłowo-handlowe. F. List przekonywał, że każde stadium wymaga innego podejścia i prowadzenia polityki handlowej, jednak wszystko powinno być podporządkowane nadrzędnemu celowi, jakim jest awans do coraz wyższych stadiów rozwoju. Zdaniem Lista, wolny handel z lepiej rozwiniętymi państwami pozwala na przejście ze stadium dzikości do pasterstwa, a później

\footnotetext{
${ }^{3}$ Część opracowań wskazuje, że F. List jest twórcą szkoły narodowej, która stała się bezpośrednim przyczynkiem
} do powstania szkoły historycznej, nie zaś jej przedstawicielem. 
rolnictwa. Kolejne szczeble rozwoju wymagają zupełnie innej polityki, bowiem nie można dopuścić do nadmiernej dominacji narodu dysponującego dobrze prosperującym przemysłem. F. List proponowal zatem wprowadzenie protekcji na rzecz przemysłu raczkującego. Było to o tyle istotne, że ówczesna Anglia zyskiwała coraz większą przewage w rozwoju gospodarczym, a jego kraj stanowił przykład słabiej rozwiniętego. List podkreślał, że mniej rozwinięte kraje nie mają szans na konkurowanie i dorównanie lepiej rozwiniętym krajom. Wynika to z faktu, że początkowo koszty rozwoju przemysłu są wyższe, a przewagą krajów lepiej rozwiniętych jest to, że w danej dziedzinie „byli pierwsi” (List, 1856, s. 119). Państwa mniej rozwinięte dzięki protekcjonizmowi mogą nabierać doświadczeni i umiejętności, które pozwolą uruchomić potencjał produkcyjny i nawiązać konkurencję $\mathrm{z}$ bardziej rozwiniętymi krajami. Co ciekawe za ochroną przemysłu raczkującego opowiadali się również John Stuart Mill, Alfred Marshall i Frank Taussig oraz Paul Samuelson.

F. List zaproponował, żeby protekcja handlowa przybierała następujące formy: prohibicja, cła na towary importowane, ograniczenia w dostępie drogą morską oraz subsydia na eksport (List, 1856, s. 73). Co istotne, ograniczenia te nie powinny być stosowane w przypadku produktów rolnych. Niemiec dostrzegał fakt, że działania te niosą ze sobą straty, bo towary w kraju mogą być droższe, ale przy tym nie można zapominać, że prowadzi to do wzrostu potencjału produkcyjnego. Wprowadzenie ceł musi być poprzedzone dogłębną analiza, bowiem musi istnieć pewność, że rzeczywiście prowadzą one do rozwoju gospodarczego, a nie hamuja go (List, 1856, s. 73). Konieczne jest rozważanie aktualnej sytuacji konkretnego państwa i porównanie dysproporcji między nim a krajem bardziej rozwiniętym (List, 1856, s. 389-390). Przekonywał, że formułowanie ogólnych zaleceń nie ma racji bytu.

Przedstawiciele młodszej szkoły historycznej, m.in.: Gustav von Schmoller, Werner Sombart oraz Max Weber $\mathrm{w}$ najważniejszych kwestiach podzielali zdanie F. Lista i przedstawicieli starszej szkoły historycznej. Podkreślali oni bowiem, że najistotniejszym podmiotem na rynku jest państwo narodowe. To państwo a nie rynek jest niezawodne. Rynek zawodzi bowiem $\mathrm{w}$ rozpoczęciu procesu industrializacji a państwo skutecznie rozwiązuje problemy ekonomiczne i społeczne dzięki reformom. Państwo, a nie mechanizm rynkowy, kształtuje ład w gospodarce, a przy tym wspiera rozwój przemysłu (oddziałuje na tempo akumulacji kapitału oraz proces uprzemysłowienia gospodarki). Ekonomiści młodszej szkoły historycznej podkreślali, że nie występuje sprzeczność między silnym państwem a wolnością jednostki, wręcz przeciwnie - wolność uzależniona jest od silnego państwa. W ramach swoich działań państwo powinno chronić rodzimą produkcję przed szkodliwą obcą konkurencja, zwłaszcza angielska, wykorzystując przy tym cła (Danowska-Prokop, 2015, s. 24-26).

\section{Teoretycy współczesnego protekcjonizmu}

Wielu badaczy zajmuje się problematyką polityki handlowej. Wśród nich są również $\mathrm{Ci}$, którzy są przeciwnikami wolnej, nieskrępowanej polityki handlowej. W latach 80. XX w. grupa teoretyków handlu zagranicznego przedstawiła nową koncepcję polityki handlowej znaną pod nazwą strategiczna polityka handlowa (strategic trade policy). Do jej twórców zaliczają się: James Brander, Barbara Spencer, Paul Krugman, Elhanan Helpman, Avinash Dixit, Gene Grossman i Jonathan Eaton (Mucha-Leszko, 2014, s. 145). Koncepcja 
strategicznej polityki handlowej wchodzi od założenia, że istnieje niedoskonała konkurencja i ona jest motywacją do podejmowania działań protekcjonistycznych. Podstawą tej polityki jest również stwierdzenie, że w warunkach konkurencji niedoskonałej, podejmowanie działań w polityce handlowej może okazać się bardziej skuteczne niż ich brak (Grottel, 2016, s. 76). Za pomocą analiz modelowych, twórcy tej teorii, przekonywali o korzyściach z subsydiowania eksportu i ograniczania importu. Sama nazwa strategiczna polityka handlowa wskazuje, że jej celem jest wspieranie rozwoju i eksportu strategicznych gałęzi przemysłu, zatem takich, które są szczególnie istotne dla rozwoju gospodarczego państwa oraz zwiększenia dobrobytu społecznego (Mucha-Leszko, 2014, s. 145-146).

Natomiast Dani Rodrik w swym opracowaniu „Trade Policy Reform as Institutional Reform" przekonuje, że nie istnieją kraje, które odnotowały wysoki wzrost gospodarczy tylko dzięki liberalizacji handlu międzynarodowego. Ekonomista ten jest sceptyczny wobec istnienia jednoznacznego związku pomiędzy otwartością handlową i wzrostem. Zdaniem D. Rodrika instytucjonalne otoczenie, w którym działa polityka handlowa, ma większe znaczenie dla wyników ekonomicznych niż poziomy, na których ustalane są bariery handlowe. Nawiązując do Lina i Nugenta, Rodrik definiuje instytucje jako zbiór ludzkich reguł behawioralnych, które rządzą i kształtuja interakcje. Ekonomista zauważa, że członkostwo w WTO pociaga za sobą reformy instytucjonalne, które są wymagające. Zastanawiał się przy tym czy koszt reform i dostosowań nie jest za wysoki szczególnie dla krajów rozwijających się, które mogłyby te pieniądze przekazać na cele rozwojowe. Zmiany instytucjonalne są kosztowne i wymagają nakładów związanych z ograniczonymi zasobami ludzkimi, zdolnościami administracyjnymi i kapitałem politycznym. Mocne powiązania z gospodarką światową mają również inne, bardziej subtelne wymagania instytucjonalne. Otwartość wiąże się z ekspozycją na ryzyko zewnętrzne, a co za tym idzie zwiększa się popyt na ubezpieczenia.

D. Rodrik przekonuje, że kluczem do sukcesu jest połączenie możliwości oferowanych przez rynki światowe $z$ krajową strategią inwestycyjną $i$ budowaniem instytucji w celu pobudzania ducha przedsiębiorczości. Dla potwierdzenia powyższej tezy ekonomista przywołuje przykład krajów Azji Wschodniej - Chin, Korei Południowej i Tajwanu. Dzięki częściowej liberalizacji handlu i otwarciu gospodarki na bezpośrednie inwestycje zagraniczne, połączonej z reformami instytucjonalnymi, udało się tam, na początku lat osiemdziesiątych, przyspieszyć rozwój gospodarczy. Rządy krajów azjatyckich stosowały m.in. subsydia eksportowe, kredyty, ograniczenia w przepływie kapitału oraz surowe wymagania stawiane przed produktami importowymi.

Równocześnie Rodrik sugeruje, że pojawiająca się w literaturze tendencja do przeceniania znaczenia otwartości handlu dla wzrostu gospodarczego nie ma podstaw w badaniach empirycznych. Zdaniem ekonomisty zależność ta prawdopodobnie jest przypadkowa. Wskazówką może być fakt, że prawie wszystkie dzisiejsze kraje rozwinięte zaczęły się rozwijać z barierami celnymi, a ochrona została ograniczona dopiero później. Rodrik odnosi się również do nowoczesnej teorii endogenicznego wzrostu, która jego zdaniem daje niejednoznaczną odpowiedź na pytanie, czy liberalizacja handlu sprzyja wzrostowi. Odpowiedź jest różna w zależności od tego czy siły przewagi komparatywnej przesuwają zasoby gospodarki w kierunku działan generujących długoterminowy wzrost czy też odwracając je od takiego działania.

D. Rodrik nie twierdzi przy tym, że ochrona handlu jest ściśle związana z wyższym wzrostem. Zwraca uwagę na fakt, że kiedy inne istotniejsze cele strategiczne konkurują o ograniczone zasoby, głęboka liberalizacja handlu nie powinna być priorytetem. Jest to 
szczególne istotna wskazówka dla krajów, które są na wczesnym etapie reform (Rodrik, 2000, s. 15-17).

Podsumowując swoje dzieło, Rodrik sugeruje, że reforma polityki handlowej przyczynia się do rozwoju gospodarczego, tylko wtedy, gdy budowane są instytucje wysokiej jakości. Rząd wdrażający zmiany powinien się przede wszystkim zastanowić czy reforma poprawi jakość instytucji w kraju. Kwestie związane ze zwiększeniem wolumenu handlu, uczynieniem reżimu handlowego bardziej liberalnym oraz zwiększeniem dostępu do rynku za granica, to kwestie drugorzędne (Rodrik, 2000, s. 18).

\section{Cechy współczesnego protekcjonizmu}

Rozkwit międzynarodowej polityki handlowej nastąpił wraz z podpisaniem Układu Ogólnego w sprawie Taryf Celnych i Handlu (GATT 1947 r.) oraz kolejnymi rundami negocjacyjnymi organizowanymi przez sygnatariuszy tego porozumienia. Dzięki temu stworzono międzynarodowe zasady ograniczające protekcjonizm oraz niepewność w stosunkach handlowych. Na bazie działań GATT utworzono Światową Organizację Handlu, która kontynuuje misje dalszej liberalizacji handlu oraz administruje dotychczas wynegocjowanymi porozumieniami (Wojtas, 2015, s. 392). Aktualnie polityka handlowa większości państw, oparta jest na mieszance elementów wolnego handlu $\mathrm{z}$ formami interwencji. Hybrydowy charakter prowadzonej polityki handlowej czyli teoretyczne propagowanie wolnego handlu przy jednoczesnym stanowieniu instrumentów protekcjonizmu w narodowej polityki gospodarczej jest szczególne niebezpieczne, wprowadza zamęt i niezrozumienie u partnerów handlowych (Dugiel, 2009, s. 29).

W neoprotekcjonizmie ujawniają się również cechy regionalizmu, od nowego stulecia multilateralna liberalizacja jest wypierana przez porozumienia bilateralne i regionalne. Protekcjonizm wykorzystywany jest do podziału rynku światowego.

Warto dodać, że do tradycyjnych argumentów przemawiających za stosowaniem protekcjonizmu, takich jak ochrona nowych gałęzi przemysłu, ochrony dochodów i zatrudnienia, dołączyły nowe uzasadnienia stosowania ochrony handlowej. Wśród nich argument o negatywnym wpływie nadmiernej otwartości wobec handlu zagranicznego na stabilność i autonomię kształtowania polityki ekonomicznej państwa w skali makroekonomicznej. Argument ten wspiera teza, że wysoki lub wzrastający w szybkim tempie udział handlu zagranicznego w gospodarce, zwiększa podatność gospodarki na zakłócenia zewnętrzne i utrudnia utrzymanie jej makroekonomicznej stabilności. Co więcej każde państwo stara się unikać nadmiernego uzależnienia od importu określonego towaru. Grozi to zakłóceniami w jego dostawach (Puślecki, 1992, s. 109-110).

Wielostronne rokowania handlowe prowadzone w ramach GATT i WTO sprawiły, że cła zostały w znacznym stopniu obniżone, zatem we współczesnej ochronie handlowej przeważają środki pozataryfowe. Wiele krajów decyduje się na prowadzenie strategicznej polityki handlowej czy polityki przemysłowej. Co więcej działanie te są stosowane selektywnie wobec wybranych, najbardziej zagrożonych gałęzi produkcji tzw. wrażliwych gałęzi.

Strategiczna polityk handlowa wskazuje jak określone państwo może, kosztem partnera, uzyskać korzyści z wprowadzenia subsydiów. Dla wyjaśnienia istoty tej polityki najlepiej posłużyć się przykładem prezentowanym przez P. Krugmana, dotyczącym konkurencji między Boeingiem i Airbusem. Nie licząc niewielkich firm, te dwa 
przedsiębiorstwa zdominowały światowy rynek samolotów pasażerskich, zatem można założyć, że sytuacja jest zbliżona do klasycznego duopolu. Przedsiębiorstwa te co jakiś czas stają przed dylematem dotyczącym budowy nowych modeli. Największym problemem dla tych podmiotów jest wielkość popytu. Boeing i Airbus ponoszą ogromne koszty w trakcie trwających wiele lat faz projektowania, konstruowania i uruchamiania produkcji dlatego tak istotne są deklaracje linii lotniczych gotowych kupić najnowsze modele oraz prognozowanie popytu. Zdaniem Krugmana subsydia rządowe zmieniają znacząco sytuację obu podmiotów, stwarzając możliwość osiagania większych zysków oraz korzyści skali przez przedsiębiorstwo otrzymujące pomoc. Co więcej, pomoc ta oddziałuje pozytywnie nie tylko na przedsiębiorstwo, ale również na całą gospodarkę (Budnikowski, 2006, s. 227-230).

Natomiast polityka przemysłowa opiera się na działaniach państwa zmierzających do rozwoju gałęzi i branż przemysłu, które uznawane są za nowoczesne. W ramach wspierania nowoczesnego przemysłu państwa stosują rożne środki m.in. subsydiowanie prac badawczych i rozwojowych, tanie kredyty, gwarancje kredytowe, ulgi podatkowe czy odstępstwa od stosowania niektórych przepisów antymonopolowych. Japonia uznawana jest za prekursora polityki przemysłowej, bowiem po zakończeniu II Wojny Światowej państwo to zaangażowało się w kształtowanie struktury przemysłu, stawiając na przemył samochodowy, elektroniczny czy stalowy. Z Japonii przykład wzięła m.in. Francja, która w latach sześćdziesiątych i siedemdziesiątych XX w. wspierała przemysł lotniczy, telekomunikację, technologie komputerowe oraz energetykę (Budnikowski, 2006, s. 230-231).

Mariana Mazzucato w książce „Przedsiębiorcze państwo. Obalić mit o relacji sektora publicznego $i$ prywatnego" przekonuje, że zaangażowanie państwa w rozwój innowacyjnych wynalazków jest niezbędne. Za przykład podaje ona m.in. Japonię, która prowadziła działania wspierające przedsięwzięcia innowacyjne. Kraj ten odniósł sukces, ponieważ tworzone były powiązania między firmami, sektorem prywatnym oraz publicznym, które zapewniały całościowy wzrost gospodarczy (Mazzucato, 2016, s. 60). M. Mazzucato wspomina również o polityce prowadzonej przez rząd amerykański. W Stanach Zjednoczonych dba się nie tylko o tworzenie bazy naukowej czy rozwój innowacyjności, rząd federalny aktywnie wspiera firmy pokroju Apple w walce o dostęp do globalnego rynku konsumenckiego czy w działaniach na rzecz zdobycia i utrzymania przewagi konkurencyjnej na rynku światowym. Co więcej, rząd amerykański oferuje wiele innych ułatwień, w tym ulgi podatkowe (Mazzucato, 2016, s. 156-158). Zupełnie inaczej wygląda sytuacja tzw. peryferyjnych państw w Europie, takich jak Włochy czy Portugalia, które nie dokonują strategicznych inwestycji (Mazzucato, 2016, s. 29).

Zdaniem Mazzucato rolą państwa jest nie tylko rozwijanie wiedzy w państwowych laboratoriach czy uniwersytetach, ale przede wszystkim mobilizowanie zasobów i podmiotów pozwalających na rozpowszechnienie wiedzy między różnymi sektorami gospodarki (Mazzucato, 2016, s. 60). Co więcej bez wsparcia państwa Internet, współczesne technologie oraz farmaceutyki nie mogłyby się dynamicznie rozwijać (Mazzucato, 2016, s. 8). M. Mazzucato przekonuje, że nie wystarczające jest mówienie o „przedsiębiorczym państwie”, należy je budować, skupiając się przede wszystkim na tworzeniu długoterminowych strategii wzrostu, a przy tym nie zrażać się nieuniknionymi porażkami. Państwo powinno podejmować działania i inwestować w kluczowe obszary jakimi są edukacja oraz badania i rozwój (Mazzucato, 2016, s. 284-285). 
Zarówno strategiczna polityka handlowa jak i polityka przemysłowa są zbieżne z polityką ochronną. Łączy je jeden cel - podwyższenie konkurencyjności krajowych podmiotów na rynku międzynarodowym. Polityka ochronna w głównej mierze koncentruje się na ograniczeniu dostępu do rynku wewnętrznego, natomiast strategiczna polityka handlowa oraz polityka przemysłowa główny nacisk kładą na podejmowanie działań usprawniających funkcjonowanie rynku wewnętrznego oraz tworzenie konkurencyjnych warunków prowadzenia działalności gospodarczej (Grottel, 2016, s. 77).

\section{Współczesny protekcjonizm w praktyce}

Współczesne działania protekcjonistyczne realizowane są przez rządy większości krajów, ale również przez instytucje ponadnarodowe jak Unia Europejska. Obecnie niewiele krajów całkowicie rezygnuje ze stosowania protekcjonizmu.

Wśród wszystkich polityk, które prowadziły Wspólnoty Europejskie, a następnie Unia Europejska, jedną z najważniejszych jest wspólna polityka rolna. Charakteryzuje się ona szczególnie wysokim stopniem protekcjonizmu. Na przestrzeni lat wykorzystywano różne instrumenty, które chroniły i nadal chronią rynek rolnych państw członkowskich Unii Europejskiej. Do instrumentów tych można zaliczyć system cen wspólnych, który polega na stosowaniu cen produktów rolnych na poziomie określonym przez Unię. Ceny te są wyższe od światowych, a ich wysokość gwarantowana jest stosowaniem zakupów interwencyjnych. Co więcej Unia Europejska stosuje jednolita politykę handlową i wspólne cło wobec państw trzecich co prowadzi do zminimalizowanie konkurencyjności importowanych produktów spoza Unii. Do takich działań można zaliczyć opłaty wyrównawcze, kontyngenty, ceny minimalne, a także restrykcyjne przepisy fitosanitarne. Instrumenty te były stosowane przede wszystkim w latach 80 . XX w. Opłaty wyrównawcze nie są już stosowane, a ceny wielu produktów kształtują się na poziomie światowym.

Unia Europejska wprowadzała również ograniczenia ilościowe, które służą zmniejszeniu poziomu produkcji określonych produktów rolnych i zapewnieniu stabilizacji rynków. Wśród produktów, których produkcja była ograniczana są m.in. mleko i cukier. Mechanizm ten charakteryzował się ustaleniem kwoty w całej Unii, która była rozdzielana pomiędzy państwa członkowskie, a następnie między poszczególnymi producentami. W przypadku gdy przekroczone zostały ustalone kwoty, powstałe nadwyżki były sprzedawane na rynku światowym, a koszt różnicy cen był dzielony między producentów i cukrownie.

Unia Europejska podejmuje decyzję zezwalające na wykorzystanie środków służących zwiększaniu dochodów rolniczych. Chodzi tu przede wszystkim o wypłacanie producentom rolnym tzw. dotacji bezpośrednich, czyli pewnej sumy pieniędzy niezależnie od dochodów ze sprzedaży swoich produktów na rynku. Unia Europejska używa również subsydiów oraz różnorakich dotacji w celu ochrony rynku rolnego. Dotowane mogą być produkty lub środki produkcji. Natomiast subsydia ułatwiają szybszą sprzedaż produktów, podtrzymując jednocześnie dochody rolników i pozwalając na rozwoju eksportu rolnego w warunkach ostrej konkurencji na rynku światowym. Wysokie subsydia produkcyjne i eksportowe, stosowane w ramach wspólnej polityki rolnej, sprawiły, że właściwie towary krajów trzecich zniknęły z części rynków eksportowych (Kocot i Niedziela-Stępień, 2006, s. 191193). 
Kryzys gospodarczy, który pojawił się w 2008 r. wymógł na Unii Europejskiej oraz państwach członkowskich specjalne działania. Unii Europejska musiała tworzyć szereg instrumentów, które nie tylko miały pomagać krajom w kłopotach, ale również tworzyć ramy solidnego zarządzania gospodarczego nie dopuszczającego do podobnej sytuacji. Efektem tych działań było przyjęcie takich dokumentów jak Traktat o stabilności, koordynacji i zarządzaniu w Unii Gospodarczej (wszedł w życie 1 stycznia 2013 r.) i Walutowej czy stworzenie Europejskiego Mechanizmu Stabilności (Traktat o utworzeniu ESM wszedł w życie we wrześniu 2012 r.). W tym samym czasie kraje członkowskie Unii Europejskiej starały się chronić własne rynki. Przykład Włoch czy Francji pokazuje, że gdy bankructwo grozi podmiotom kluczowym dla danej gospodarki, to praktyki protekcjonistyczne nie budzą dużych sprzeciwów. Kraje te podjęły bowiem decyzję o przeniesieniu produkcji z powrotem do siebie. Państwa członkowskie Unii Europejskiej, takie jak Niemcy i Wielka Brytania dofinansowały banki kosztem zagranicznej konkurencji. Zasada , too big to fail” idealnie wpisywała się w działania rządów.

Ostatni kryzys gospodarczy sprawił, że protekcjonizm na rynku towarów rolnospożywczych również przybrał na sile. Najczęściej państwa korzystały z instrumentów pozataryfowych takich jak środki stosowane na podstawie klauzul ochronnych, środki sanitarne i fitosanitarne, bariery techniczne oraz subsydia. Rzadziej z ceł, w formie stawek celnych ad valorem, specyficznych i mieszanych (Wieczorek, 2013, s. 54-55). Najwięcej zastrzeżeń dotyczących stosowania ochrony produkcji i handlu przed konkurencją zgłaszano wobec rygorystycznych przepisów odnoszących się do bezpieczeństwa żywności i środków ochrony zdrowia zwierząt, tylko w nielicznych przypadkach ochrony zdrowia roślin. Przykładami kontrowersyjnych specjalnych środków ochronnych bezpieczeństwa żywności były normy maksymalnego poziomu pozostałości pestycydów w żywności w Stanach Zjednoczonych i Japonii, obowiązujący w Unii wymóg umieszczania na opakowaniach ostrzeżeń o zawartości barwników w żywności czy restrykcje dotyczące produktów uzyskiwanych przy wykorzystaniu biotechnologii w Turcji. Wątpliwości, w ramach ochrony zdrowia zwierząt, budziły restrykcje związane z ptasią grypa, które obowiązywały w Indiach, a także przepisy w zakresie dokumentacji humanitarnych zasad uboju w Unii Europejskiej.

Barierami występującymi często $\mathrm{w}$ handlu rolno-spożywczym były również techniczne regulacje, procedury oceny zgodności z normami przemysłowymi i standardami bezpieczeństwa, a także procedury testowania i certyfikacji. Warto dodać, że w okresie kryzysu niektóre kraje wprowadziły nowe restrykcje eksportowe, głównie w wywozie surowców i produktów rolnych (Hajdukiewicz, 2012, s. 796-799).

Organizacja Współpracy Gospodarczej i Rozwoju miała świadomość, że po kryzysie tendencje protekcjonistyczne będą się nasilać dlatego od początku kryzysu podkreślała konieczność zdefiniowania czasu trwania i kierunków interwencji Zdaniem OECD niezbędne było również utworzenie planu przywracania równowagi pomiędzy rynkiem a państwem w miarę jak stabilizować się będzie sytuacja gospodarek (Luc, 2011, s. 147). Odpowiedzia na to było stworzenie dokumentu Strategic Response to the Financial and Economic Crisis: Contribution to the Global Efforts opublikowanego 23 grudnia 2008 r. Stanowił on propozycję połączenia ówczesnych przedsięwzięć stabilizacyjnych z długookresowymi reformami strukturalnymi. OECD podkreślała, że kryzys wymusza trudne decyzje, w tym wyzwania strukturalne. Należy kontynuować wysiłki na rzecz walki z ubóstwem i nierównością, utrzymania globalnych przepływów handlowych i inwestycyjnych oraz rozwoju procesów produkcyjnych. Realizacja tych zadań stwarza 
możliwości zrównoważonego rozwoju. Konieczne jest jednak zaangażowanie i współdziałanie głównych graczy. W dokumencie tym wskazano dwa priorytetowe obszary działań: finanse, konkurencyjność i zarządzanie oraz zrównoważony wzrost $\mathrm{w}$ długim okresie (OECD Strategic Response to the Financial and Economic Crisis: Contribution to the Global Efforts, C(2008)191/Final).

Tendencje do działań protekcjonistycznych nie minęły wraz ze stabilizacją sytuacji gospodarczej. Coraz częściej można usłyszeć o działaniach państw członkowskich Unii Europejskiej, które chronią własne rynki, pomimo istnienia wspólnego rynku i swobody przepływu towarów, usług, kapitału oraz osób. Doskonałym przykładem realizacji takiego celu są zwiększone, bardziej restrykcyjne kontrole sanitarne i negatywne kampanie dotyczące zagranicznych produktów. Włosi próbowali wprowadzić inne niż na terenie UE normy zawartości soków w napojach (przynajmniej $30 \%$, a nie $20 \%$ i specjalne wymagania co do opakowań. Natomiast Rumunia wprowadziła przepis, który nakłada obowiązek zakupu ponad $51 \%$ produktów mleczarskich i mięsnych u lokalnych dostawców. Problem ten nie dotyczy tylko rynku spożywczego, który właściwie został uregulowany przez dyrektywy określając normy dla każdej kategorii produktów. Głośna stała się sprawa Niemiec, które chciały wymusić wprowadzenie przepisów obligujących firmy transportowe do stosowania płacy minimalnej wobec kierowców jeżdżących na trasach międzynarodowych. Co więcej, Związek Niemieckiego Przemysłu Meblarskiego od wielu lat domaga się, by w całej UE wprowadzić obowiązkowe oznaczenia kraju pochodzenia sprzedawanych mebli bowiem dzięki wsparciu z funduszy unijnych nastąpił rozwój polskich zakładów, co pozwoliło na obniżenie kosztów i zwiększenie konkurencyjności rodzimych meblarzy (Wieczerzak-Krusińska, 2017).

Neoprotekcjonizm nie jest domeną Unii Europejskiej i jej państw członkowskich. Podobne posunięcia czyniły państwa Azji Wschodniej. Bez wątpienia azjatyckie rynki nie są monolitem, ale łączy je polityka developmental state. Karina Jędrzejowska w książce Liberalizacja $i$ protekcjonizm we wspótczesnym handlu międzynarodowym określa developmental state jako „system gospodarczy, w którym rozwój gospodarczy stanowi cel nadrzędny, którego realizację zapewnia użycie odpowiednich narzędzi przede wszystkim o charakterze protekcjonistycznym" (Wydymus i Maciejewski, 2015, s. 138). W takiej sytuacji kraje prowadzą aktywną politykę gospodarczą nakierowaną na rozwój gospodarczy. W Japonii, Korei Południowej, Singapurze, Chinach czy Tajwanie władze odwoływały się do tożsamości narodowej i ochrony interesu narodowego dla uzasadnienia działań protekcjonistycznych. Gospodarki tych państw cechuje specyficzny układ łączący sektor prywatny z państwowym, który miał prowadzić do rozwoju gospodarczego. Państwo ma szeroki wachlarz instrumentów uprawniających do kontroli i stymulowania procesów gospodarczych przez co pełni centralną rolę w systemie. Istotną cechą developmental state jest powiązanie substytucji importu i orientacji proeksportowej. W początkowej fazie rozwoju państwo szczególny nacisk kładzie na substytucje, a tym samym na ochronę własnego przemysłu oraz jego rozwój. W kolejnym etapie rząd wspiera rozwinięte gałęzie przemysłu. Wszystkim tym działaniom towarzyszy promocja narodowych marek (Wydymus i Maciejewski, 2015, s. 138-140). 


\section{Podsumowanie}

Porównanie współczesnego i XIX-wiecznego protekcjonizmu handlowego wykazało, że neoprotekcjonizm nie różni się istotnie co do celów od swojego poprzednika. Argumenty przemawiające za prowadzeniem działań protekcjonistycznych właściwie nie zmieniają się na przestrzeni lat. Podkreśla się przy tym patriotyczny charakter neoprotekcjonizmu oraz jego XIX-wiecznego odpowiednika. Różni je natomiast stosowanie odmiennych środków ochronnych. W neoprotekcjonizmie wykorzystuje się przede wszystkim bariery pozataryfowe w stosunku do wybranych gałęzi produkcji. Subsydia przekazywane są zatem do wybranych gałęzi przemysłu bądź przedsiębiorstw. Ponadto współczesna polityka handlowa ciężar praktyk protekcjonistycznych kładzie na procesy wewnętrzne mające miejsce w konkretnej gospodarce i bezpośrednio wpływające na eksport. W neoprotekcjonizmie poprzez regionalizm dzielony jest światowy rynek.

Nie można zapominać, że właśnie w okresach stagnacji gospodarczej oraz w związku z różnicami rozwojowymi między uczestnikami rynku światowego protekcjonizm handlowy ulega nasileniu. Współcześnie zauważamy teoretyczne propagowanie wolnego handlu przy jednoczesnym stanowieniu instrumentów protekcjonizmu w narodowej polityce gospodarczej.

\section{Literatura}

Budnikowski, A. (2006). Międzynarodowe stosunki gospodarcze (International Economic Relations). Polskie Wydawnictwo Ekonomiczne, Warszawa.

Danowska-Prokop, B. (2015). Państwo w gospodarce - poglądy przedstawicieli młodszej szkoły historycznej (The Station in the Economy - the View of Representatives of the Younger Historical School). Zeszyty Naukowe Uniwersytetu Ekonomicznego w Katowicach, 236, 21-34.

Dugiel, W. (2009). Zmiany w światowym systemie handlu. Perspektywa dla Unii Europejskiej (Changes within World Trade System. Prospects for the European Union). Centrum Europejskie Natolin, Warszawa.

Encyklopedia Britannica Friedrich List (Britannica Encyclopedia Friedrich List). Pobrano 5 października 2017 z: https://www.britannica.com/biography/Friedrich-List.

Grottel, M. (2016). Protekcjonizm we współczesnym handlu międzynarodowym (Protectionism in contemporary international trade). International Business and Global Economy, 35/1, 69-80.

Hajdukiewicz, A. (2012). Protekcjonizm w handlu rolnym w czasach globalnego kryzysu i jego implikacje (Protectionism in Agricultural Trade in Times of the Global Crisis and Its Implications). Prace i Materiaty Instytutu Handlu Zagranicznego Uniwersytetu Gdańskiego, 31, 786-802.

Jędrzejowska, K. (2015). Merkantylizm i nacjonalizm ekonomiczny w polityce gospodarczej wschodnioazjatyckich rynków wschodzących (Mercantilism and Economic Nationalism in the Economic Policy of East Asian emerging markets). W: S. Wydymus, M. Maciejewski (red.), Liberalizacja i protekcjonizm we współczesnym handlu międzynarodowym (Liberalization and Protectionism in Contemporary International Trade), 133-145, CeDeWu, Poznań.

Kocot, M., Niedziela-Stępień, A. (2006). Polityka rolna Unii Europejskiej na tle liberalizacji światowego handlu (The Common Agricultural Policy on the Background of Liberalization of World Trade). Studia Ekonomiczne, 38, 189-199.

Landreth, H., Colander, D.C. (2005). Historia myśli ekonomicznej (History of Economic Thought). PWN, Warszawa.

List, F. (1856). National System of Political Economy. J.B. Lippincott \& Co., Philadelphia.

Luc, S. (2011). Koordynacja polityki w Unii Europejskiej w obliczu kryzysu ekonomicznego (Coordination of European Union Policy in View of Economic Crisis). Prace i Materiaty Instytutu Rozwoju, 85, 145-167.

Mazzucato, M. (2016). Przedsiębiorcze państwo. Obalić mit o relacji sektora publicznego i prywatnego (The Entrepreneurial State: Debunking Public vs. Private Sector Myths). [t1. Joanna Bednarek], Wydawnictwo Ekonomiczne Heterodox, Poznań. 
Mucha-Leszko, B. (2014). Globalna czy regionalna liberalizacja handlu międzynarodowego? (International Trade Liberalization - Global or Regional?). Zeszyty Naukowe Uniwersytetu Szczecińskiego. Wspótczesne Problemy Ekonomiczne. Globalizacja. Liberalizacja. Etyka, 8, 143-154.

OECD, Strategic Response to the Financial and Economic Crisis: Contribution to the Global Efforts, C(2008)191/Final.

Puślecki, Z.W. (1992). Tradycyjne i nowe argumenty protekcjonizm handlowego na przykładzie Wspólnoty Europejskiej (Tradition and New Arguments for Trade Protectonism on the Example of the EEC). Ruch Prawniczy, Ekonomiczny i Socjologiczny, 54(1), 99-114.

Rodrik, D. (2000). Trade Policy Reform as Institutional Reform. Manuscript, Harvard University.

Staniewicz, W. (2007). Historia myśli ekonomicznej (History of Economic Thought). PWN, Warszawa.

Szarzec, K. (2013). Państwo w gospodarce. Studium teoretyczne - od Adama Smitha do współczesności (State in the Economy. Theoretical Study - from Adam Smith to the Present Day). PWN, Warszawa.

Wieczerzak-Krusińska, A. (2017). Wewnątrz Unii Europejskiej rośnie protekcjonizm (Protectionism is Growing within the European Union). Rzeczpospolita. Pobrano 16 października 2017 z: http://www.rp.pl/Gospodarka/ 301169877-Wewnatrz-Unii-Europejskiej-rosnie-protekcjonizm.html.

Wieczorek, J. (2013). Protekcjonizm pozataryfowy - nowa odsłona (Non-Tariff Protectionism - New Stage). Myśl Ekonomiczna i Polityczna, 1(40), 41-66.

Wojtas, M. (2015). Międzynarodowa polityka handlowa w XXI wieku - główne trendy (International Trade Policy in the XXI Century - Main Trends). Zeszyty Naukowe Uniwersytetu Szczecińskiego. Studia i Prace Wydziału Nauk Ekonomicznych i Zarzadzania, 41(1), 391-403.

Do cytowania / For citation:

Kłosowicz-Toborek K. (2018). Istota protekcjonizmu w dziewiętnastym wieku oraz współcześnie. Problemy Rolnictwa Światowego, 18(1), 88-99; DOI: 10.22630/PRS.2018.18.1.8

Kłosowicz-Toborek K. (2018). The Essence of Protectionism in the Nineteenth Century and Nowadays (in Polish). Problems of World Agriculture, 18(1), 88-99;

DOI: $10.22630 /$ PRS.2018.18.1.8 